\title{
SPATIOTEMPORAL DYNAMICS OF SOIL PENETRATION RESISTANCE OF RECULTIVATED SOIL
}

\author{
GALINA ZADOROZHNAYA
}

Department of Human and Animal Physiology, Oles Honchar Dnipro National University, pr. Gagarina, 72, 49010 Dnipro, Ukraine; e-mail: zadorojhnayagalina@gmail.com

\begin{abstract}
Zadorozhnaya G.: Spatiotemporal dynamics of soil penetration resistance of recultivated soil. Ekológia (Bratislava), Vol. 37, No. 1, p. 82-89, 2018.

This article examines changes in the spatial distribution of soil penetration resistance in ordinary chernozem (Calcic Chernozem) and in the recultivated soil in 2012 and 2014. The measurements were carried out in the field using an Eijkelkamp penetrometer on a regular grid. The depth of measurement was $50 \mathrm{~cm}$, the interval was $5 \mathrm{~cm}$. The indices of variation of soil penetration resistance in space and time have been determined. The degree of spatial dependence of soil penetration resistance has been determined layer by layer. The nature of temporal dynamics of soil penetration resistance of chernozem and technical soil has been described. A significant positive relationship of the structure of chernozem in the two years of the research has been shown. Significant correlations between the data of different years in the technical soil were found to be mostly negative.
\end{abstract}

Key words: soil penetration resistance, recultivation, geostatistics, spatial distribution of data.

\section{Introduction}

The specific role of soil in ecosystems gives a high degree of relevance to research of anthropogenic soil processes (Brady, Weil, 2002; Karpachevskij et al., 2007). The strongest anthropogenic impacts are suffered by the soil that is formed by the extraction of mineral deposits through open-cut mining (technical soils). They go through the stages of complete destruction of the soil body and creation of a new one (Yeterevska et al., 2008; Uzbek et al., 2010). Substrates are formed by waste disposal areas of the mining industry. Theoretically, such soils can be considered as models of young natural soil. From a practical standpoint, the study of such soils is necessary to solve the problems of their economic use (Ditsch, Collins, 2000). It is known that soil formation under the man's influence proceeds more actively than in adjacent conditionally natural ecosystems (Gerasimova et al., 2003; Medvedev, 2014). Cases of increase in speed of soil processes in conditions of contamination with foreign compounds, secondary salinization during irrigation, periodic deep ploughing have been described (Nikiforova, Solntseva, 1982; Solntseva, Rubilina, 1987; Gerasimova et al., 2003). Due to the youth of the reclaimed soils, a large number of particular processes occurring in them remain unclarified. 
To assess the condition of the soil body, the soil penetration resistance index is applied (Bölenius et al., 2006; Medvedev, 2009; Alvarez et al., 2009). This emulates the living conditions of soil inhabitants (Lipiec, Tarkiewicz, 1990; Vanags et al., 2004; Godefroid, Koedam, 2004; Langmaack et al., 2002). At the same time, the variation in soil penetration resistance correlates with the change in most properties important for soil fertility (Vachel, Ehrlich, 1988; Grunwald et al., 2001; Vanags et al., 2004; Topp et al., 2003; Bajla, Minarik, 2003; Bölenius et al., 2006). The objective of this study is a comparative analysis of temporal changes in the spatial variation of soil penetration resistance of recultivated soil and natural soil.

\section{Material and methods}

The soil penetration resistance was studied in the field environment to a depth of up to 50 at $5 \mathrm{~cm}$ intervals. A hand penetrometer Eijkelkamp was used in the study (Young et al., 2000; Grunwald et al., 2001; Bengough et al., 2001; Cecilia et al., 2012; Zhukov, Zadorozhnaya, 2016). The average error of the measurement results of the device is $\pm 8 \%$. Soil penetration resistance was measured using a cone with a cross-section of $2 \mathrm{~cm}^{2}$ in each section of the test site.

Ordinary chernozem (Calcic Chernozem) was selected for study as natural soil (control). The test site is located in a steppe area adjacent to the south-eastern slope of the Kamenistaya Gully (southern outskirts of the city of Dnipro, Ukraine), $48^{\circ} 38^{\prime} 67^{\prime \prime} \mathrm{N}, 35^{\circ} 09^{\prime} 05^{\prime}$ E. The soil penetration resistance of the technical soil was studied at

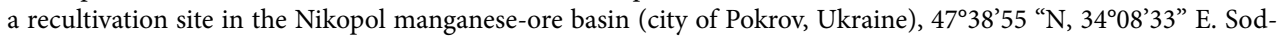
lithogenic soil on red-brown clays was chosen as the substrate. The landfill was created 40 years ago. Currently, crops are not cultivated on the test sites, though cereals and beans grow there in feral condition.

The material was collected in June 2012 and 2014 . The test sites are a regular grid of $7 \times 15 \mathrm{~m}$. The distance between the sampling points was $3 \mathrm{~m}$. Accordingly, the dimensions of each test site were $18 \times 42 \mathrm{~m}$.

In statistical calculations, the methods of descriptive statistics were used. To determine the level of spatial dependence of soil penetration resistance parameters, geostatistical analysis of data was applied (Verones et al., 2006; Webster, Oliver, 2007; Diggle, Ribeiro, 2007; Calderon et al., 2008; Chien et al., 1997). The spatial dependence level (SDL) was calculated by the formula:

$S D L=\frac{C_{0}}{C_{0}+C_{1}} \times 100$,

where $\mathrm{C}_{0}$ is the nugget-effect, $\mathrm{C}_{1}$ is the partial sill.

The indices for $\mathrm{C}_{0}, \mathrm{C}_{1}$ and the range $(R)$ were obtained on the basis of simulations of variograms of spatial variability of soil penetration resistance (Legendre, Fortin, 1989; Grunwald et al., 2001; Webster, Oliver, 2007).

The degree of conjugation of the spatial distribution of the soil body indices in different years of the study was established by means of correlation analysis.

\section{Results}

Chernozem has less absolute soil penetration resistance factors than recultivated soil. The average values of chernozem soil penetration resistance did not exceed $2.67 \pm 0.07 \mathrm{MPa}(\mathrm{Ta}-$ ble 1). The technical soil penetration resistance value was much higher. The maximum values in 2012 , were $8.42 \pm 0.33 \mathrm{MPa}$, and in 2014 were $6.71 \pm 0.15 \mathrm{MPa}$. The reason for this is the direct dependence of soil penetration resistance on humidity (Umarova et al., 2013). Recultivated soil quickly loses moisture due to the low content of organic matter and the absence of water-resistant structure (Zhukov et al., 2013; Demidov et al., 2013). Soil penetration resistance data were more variable in the upper soil layers. The greatest values of the variation coefficient corresponded to the layer of $5-10 \mathrm{~cm}$ from the surface in all cases. 
$\mathrm{T}$ a b l e 1. Parameters of spatial variation of soil penetration resistance.

\begin{tabular}{|c|c|c|c|c|c|c|c|c|}
\hline \multirow{2}{*}{$\begin{array}{l}\text { Distance from } \\
\text { the surface, } \mathrm{cm}\end{array}$} & \multicolumn{4}{|c|}{ Ordinary chernozem } & \multicolumn{4}{|c|}{ Recultivated soil } \\
\hline & $\begin{array}{c}\mathrm{x} \pm \mathrm{SE} \\
\mathrm{MPa}\end{array}$ & $\begin{array}{c}\mathrm{CV} \\
\%\end{array}$ & $\begin{array}{c}\text { SDL, } \\
\%\end{array}$ & $\begin{array}{l}\mathbf{R}, \\
\mathbf{m}\end{array}$ & $\begin{array}{c}\mathrm{x} \pm \mathrm{SE} \\
\mathrm{MPa}\end{array}$ & $\begin{array}{c}\mathrm{CV}, \\
\%\end{array}$ & $\begin{array}{c}\text { SDL, } \\
\%\end{array}$ & $\begin{array}{l}\mathbf{R}, \\
\mathbf{m}\end{array}$ \\
\hline \multicolumn{9}{|c|}{2012} \\
\hline $0-5$ & $2.04 \pm 0.07$ & 32.71 & 27.8 & 6.91 & $3.26 \pm 0.09$ & 41.1 & 2.09 & 4.49 \\
\hline $5-10$ & $2.14 \pm 0.08$ & 39.75 & 17.21 & 6.32 & $4.57 \pm 0.17$ & 42.7 & 6.60 & 4.31 \\
\hline $10-15$ & $2.12 \pm 0.08$ & 38.02 & 28.39 & 4.53 & $5.58 \pm 0.19$ & 40.0 & 13.07 & 3.52 \\
\hline $15-20$ & $2.15 \pm 0.07$ & 31.04 & 30.4 & 4.20 & $6.31 \pm 0.22$ & 39.4 & 12.81 & 3.34 \\
\hline $20-25$ & $2.13 \pm 0.06$ & 28.57 & 26.87 & 4.38 & $6.96 \pm 0.25$ & 35.4 & 13.09 & 3.79 \\
\hline $25-30$ & $2.14 \pm 0.06$ & 28.12 & 25.67 & 5.07 & $7.39 \pm 0.27$ & 36.5 & 17.13 & 4.06 \\
\hline $30-35$ & $2.15 \pm 0.06$ & 27.49 & 28.16 & 5.22 & $7.79 \pm 0.29$ & 37.3 & 15.61 & 4.30 \\
\hline $35-40$ & $2.23 \pm 0.06$ & 26.53 & 32.22 & 4.76 & $8.24 \pm 0.31$ & 38.7 & 18.96 & 4.11 \\
\hline $40-45$ & $2.40 \pm 0.06$ & 26.35 & 34.73 & 4.92 & $8.42 \pm 0.33$ & 38.2 & 21.29 & 4.19 \\
\hline $45-50$ & $2.67 \pm 0.07$ & 25.25 & 32.72 & 4.90 & $8.06 \pm 0.35$ & 29.6 & 18.92 & 4.04 \\
\hline \multicolumn{9}{|c|}{2014} \\
\hline $0-5$ & $1.45 \pm 0.04$ & 26.91 & 22.27 & 9.83 & $2.05 \pm 0.09$ & 47.31 & 18.52 & 3.86 \\
\hline $5-10$ & $1.54 \pm 0.05$ & 33.09 & 20.60 & 9.06 & $3.89 \pm 0.14$ & 38.01 & 21.48 & 5.01 \\
\hline $10-15$ & $1.52 \pm 0.05$ & 32.21 & 17.30 & 10.14 & $4.90 \pm 0.10$ & 20.57 & 25.10 & 5.60 \\
\hline $15-20$ & $1.54 \pm 0.03$ & 22.92 & 31.01 & 6.72 & $5.44 \pm 0.06$ & 11.70 & 31.13 & 3.67 \\
\hline $20-25$ & $1.51 \pm 0.03$ & 20.63 & 31.00 & 7.44 & $5.64 \pm 0.06$ & 11.58 & 34.23 & 3.62 \\
\hline $25-30$ & $1.48 \pm 0.03$ & 22.45 & 30.22 & 6.51 & $5.93 \pm 0.12$ & 20.20 & 42.71 & 3.53 \\
\hline $30-35$ & $1.52 \pm 0.04$ & 24.07 & 32.17 & 5.42 & $5.95 \pm 0.14$ & 24.97 & 52.47 & 4.57 \\
\hline $35-40$ & $1.71 \pm 0.04$ & 24.14 & 27.68 & 7.05 & $6.11 \pm 0.14$ & 23.97 & 46.48 & 3.73 \\
\hline $40-45$ & $2.08 \pm 0.05$ & 24.74 & 26.09 & 6.82 & $6.46 \pm 0.15$ & 23.90 & 50.80 & 4.53 \\
\hline $45-50$ & $2.46 \pm 0.06$ & 24.28 & 25.56 & 6.34 & $6.71 \pm 0.15$ & 22.29 & 60.87 & 4.09 \\
\hline
\end{tabular}

Notes: $\mathrm{x}$ - is an average value (MPa); $\mathrm{SE}$ - is the standard error; CV - is the coefficient of variation (\%); SDL - is the spatial dependence level (\%); $\mathrm{R}$ - is the radius of influence $(\mathrm{m})$.

The lower the SDL value, the greater the spatial dependence of these data. A higher level of spatial dependence is described in the data for the upper layers of the soils studied. In the upper layers, the bulk of the roots of plants and soil animals is concentrated. Their vital activity has a structuring effect on the soil and increases the level of spatial dependence.

The semivariogram range $(\mathrm{R})$ shows the distance at which the geostatistic model first flattens out or in our case the distance over which the mutual spatial influence of the soil masses spreads. In general, this indicator is higher in chernozem than in technical soil. During the two years of study, the radius of influence decreased with depth, while in recultivated soil it increased.

Based on the geostatistical data, maps of the layered distribution of soil penetration resistance in the soils studied were designed (Fig. 1).

Darker areas indicate increased soil penetration resistance. The transition to the areas of lesser soil penetration resistance has a gradient character. With increased depth the pattern 
A

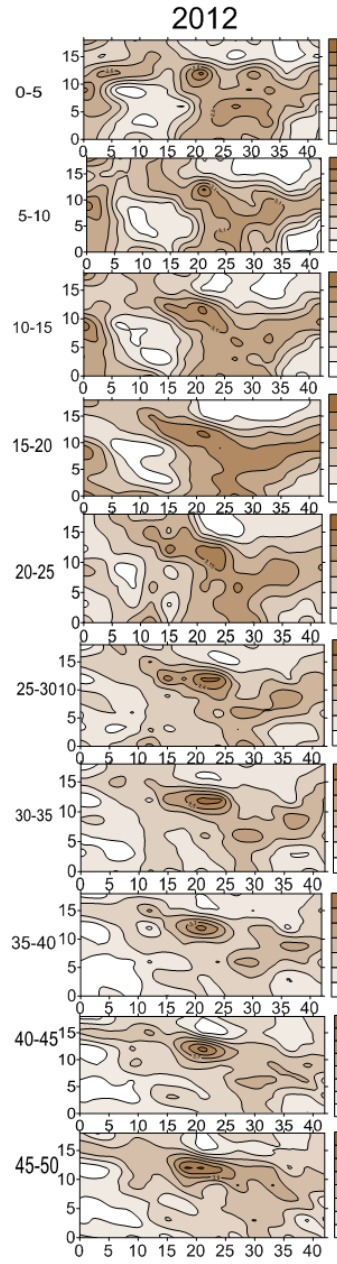

2014

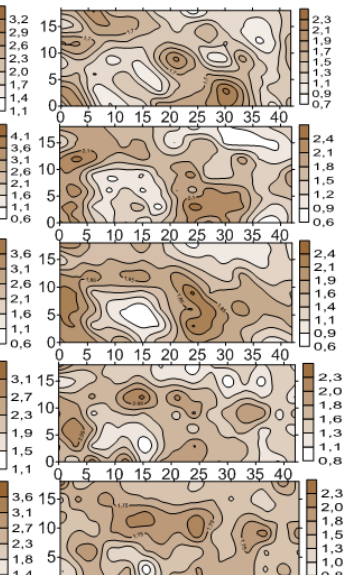

B

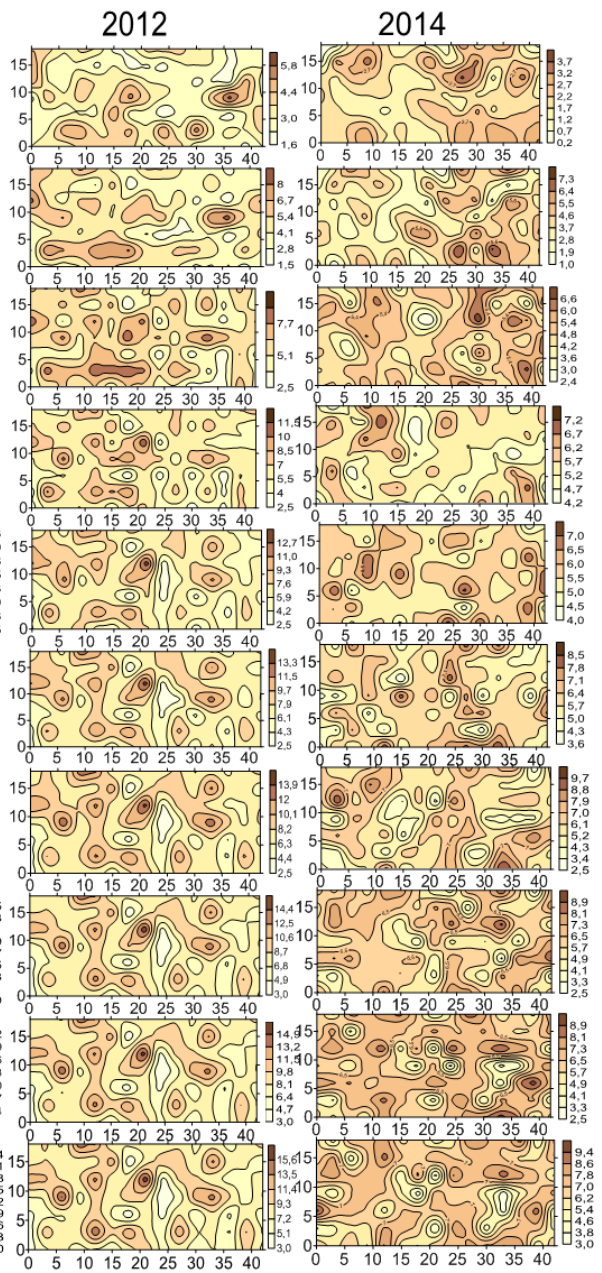

Fig. 1. Maps of spatial distribution of soil penetration resistance indicators in chernozem (A) and in technical soil (B) by layers in 2012 and 2014.

Notes: The abscissa is the length of the polygon, $\mathrm{m}$, the ordinate is the width of the polygon, $\mathrm{m} ; 0-5 \ldots 95-100 \mathrm{~cm}$ is the depth of soil from the surface.

changes. One can observe a three-dimensional separation of the soil material in terms of increased soil penetration resistance. The maps of the same sites changed considerably over two years. Less solid areas appeared in place of harder ones, and vice versa.

In order to determine the quantitative measure of the soil structure relationship in different years, a correlation analysis was performed (Tables 2, 3). 
T a b l e 2. Coefficients of Pearson correlation of soil penetration resistance in ordinary chernozem in 2012 and 2014.

\begin{tabular}{|c|c|c|c|c|c|c|c|c|c|c|c|}
\hline \multirow{2}{*}{\multicolumn{2}{|c|}{ Years }} & \multicolumn{10}{|c|}{2014} \\
\hline & & $0-5$ & 5-10 & $10-15$ & $15-20$ & $20-25$ & $25-30$ & $30-35$ & $35-40$ & $40-45$ & $45-50$ \\
\hline \multirow{10}{*}{ 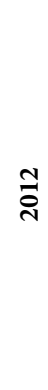 } & $0-5$ & 0.45 & 0.61 & 0.59 & 0.47 & 0.26 & 0.23 & 0.08 & 0.06 & 0.13 & 0.24 \\
\hline & $5-10$ & 0.44 & 0.67 & 0.71 & 0.58 & 0.36 & 0.30 & 0.07 & 0.03 & 0.11 & 0.26 \\
\hline & $10-15$ & 0.43 & 0.64 & 0.71 & 0.60 & 0.38 & 0.28 & 0.03 & 0.02 & 0.06 & 0.19 \\
\hline & $15-20$ & 0.32 & 0.54 & 0.63 & 0.54 & 0.38 & 0.25 & -0.01 & 0.00 & 0.03 & 0.19 \\
\hline & $20-25$ & 0.21 & 0.38 & 0.46 & 0.43 & 0.38 & 0.32 & 0.07 & 0.16 & 0.14 & 0.26 \\
\hline & 25-30 & 0.16 & 0.26 & 0.31 & 0.37 & 0.42 & 0.42 & 0.23 & 0.26 & 0.19 & 0.26 \\
\hline & $30-35$ & 0.12 & 0.20 & 0.22 & 0.19 & 0.30 & 0.40 & 0.36 & 0.34 & 0.23 & 0.26 \\
\hline & $35-40$ & 0.10 & 0.14 & 0.11 & 0.11 & 0.31 & 0.45 & 0.46 & 0.43 & 0.28 & 0.31 \\
\hline & $40-45$ & 0.10 & 0.13 & 0.06 & 0.04 & 0.28 & 0.48 & 0.51 & 0.50 & 0.33 & 0.36 \\
\hline & $45-50$ & 0.14 & 0.26 & 0.18 & 0.18 & 0.33 & 0.48 & 0.44 & 0.37 & 0.25 & 0.31 \\
\hline
\end{tabular}

Notes: $0-5, \ldots, 45-50$ is the distance from the surface $(\mathrm{cm})$; statistically significant correlations $(p<0.05)$ are shown in bold.

T a b l e 3. Pearson correlation coefficients of soil penetration resistance of recultivated soil in 2012 and 2014.

\begin{tabular}{|c|c|c|c|c|c|c|c|c|c|c|c|}
\hline \multirow{2}{*}{\multicolumn{2}{|c|}{ Years }} & \multicolumn{10}{|c|}{2014} \\
\hline & & $0-5$ & 5-10 & $10-15$ & $15-20$ & $20-25$ & $25-30$ & $30-35$ & $35-40$ & $40-45$ & $45-50$ \\
\hline \multirow{10}{*}{ 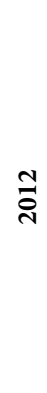 } & $0-5$ & -0.12 & -0.05 & -0.06 & -0.20 & 0.03 & 0.07 & -0.19 & -0.17 & -0.19 & -0.23 \\
\hline & $5-10$ & -0.28 & -0.21 & -0.19 & -0.06 & -0.05 & -0.14 & -0.27 & -0.21 & -0.30 & -0.30 \\
\hline & $10-15$ & -0.26 & -0.28 & -0.28 & 0.03 & -0.11 & -0.23 & -0.32 & -0.34 & -0.30 & -0.27 \\
\hline & $15-20$ & -0.17 & -0.25 & -0.14 & 0.20 & -0.02 & -0.08 & -0.17 & -0.21 & -0.21 & -0.20 \\
\hline & $20-25$ & -0.15 & -0.28 & -0.18 & 0.17 & -0.08 & -0.13 & -0.17 & -0.17 & -0.15 & -0.15 \\
\hline & $25-30$ & -0.15 & -0.24 & -0.16 & 0.20 & -0.07 & -0.10 & -0.14 & 0.15 & -0.08 & -0.12 \\
\hline & $30-35$ & -0.13 & -0.20 & -0.14 & 0.20 & -0.02 & -0.07 & -0.16 & -0.14 & -0.08 & -0.11 \\
\hline & $35-40$ & 0.15 & -0.21 & 0.15 & 0.20 & -0.04 & -0.09 & -0.16 & 0.15 & -0.10 & -0.13 \\
\hline & $40-45$ & -0.14 & -0.21 & -0.16 & 0.20 & -0.04 & -0.11 & -0.16 & 0.15 & -0.09 & -0.12 \\
\hline & $45-50$ & -0.16 & -0.22 & -0.16 & 0.20 & -0.04 & -0.12 & -0.17 & 0.15 & -0.09 & -0.12 \\
\hline
\end{tabular}

Notes: see Table 2.

The spatial distribution of chernozem soil penetration resistance data in different years is strongly correlated. The structure of the upper soil layers $(0-5, \ldots, 15-20 \mathrm{~cm})$ in 2014 reliably depends on that of 2012. A similar pattern is observed in the data of the lower layers (30-35, ..., 45-50 cm) of the studied soil mass. Layers of 20-25 and 25-30 cm carry data about the past structure of the entire soil profile. The structure of the layer of $45-50 \mathrm{~cm}$ depends also on the structure of the surface layers $(0-5,5-10 \mathrm{~cm})$, which was observed 2 years previously.

The spatial distribution of soil penetration resistance of the technical soil also has much in common with the data of the preceding years. Over the two years of study, reliable correlations were observed in almost all the studied soil layers. The structure of the upper layers $(0-5, \ldots, 15-20 \mathrm{~cm})$ exerts the strongest influence on the lower layers of the soil. The most 
dependent layers are those of 5-10 and 15-20 cm. It should be noted that the correlation is mostly negative. Reliable positive coefficients are observed only in the data of the layer of $15-20 \mathrm{~cm}$ in 2014. A reliable negative correlation can be traced in all soil layers except the 20-25 cm layer.

\section{Discussion}

The results of the study show that the soil has a memory of the past structure (Targulian, Goryachkin, 2008). A high level of dependence of soil penetration resistance data distribution was revealed over the two years of research. The discovered relations in the technical soil were weaker than those of the chernozem. Reliable correlations between the data of the technical soil for the different years were mostly negative. Negative dependencies also indicate the existence of a relationship. However, they show that in the areas of increased soil penetration resistance it decreased over two years and vice versa. Most likely, the driver of such processes is vegetation. From the point of view of solid phase structural organization, anthropogenic soil is considered as a simpler system with limited buffering (Anand et al., 2002; Gerasimova et al., 2003, Serafim et al., 2008). The latter affects the stability and structure of plant aggregations. Intraspecific and interspecific relationships of plants are determined by trophic dependencies and environmental transformation (Chesson, 2000). In chernozem these relationships were formed long ago. Recultivated soils are very young. Within these soils, transformations of vegetation on them are very clearly expressed from year to year. There is a rapid change in species composition and quantitative relationships. In this context, important work has been conducted on plant communities on technical soil (Andrusevich, Stirz, 2014). This research found an expansion in a range of species with different environmental preferences in comparison with the natural community. It indicates the variability of ecological environmental regimes for the vegetation of anthropogenic soil. The share of young plants on technical soil is over 1.5 times higher than it is for the natural community. This indicates the state of dynamic transformation of vegetation on technical soils. In turn, the structure of the plant community influences the structure of the soil (Zhukov, Zadorozhnaya, 2015). Depending on the characteristics of the root systems, this effect is significant (Montagu et al., 2001; Vanags et al., 2004; Godefroid, Koedam, 2004). Rapid changes in the configuration of the plant community lead to dynamic restructuring of the soil. The presence of a large number of negative correlations between the structure of technical soil during the different years of the study confirms our assumptions.

\section{Conclusion}

The chernozem studied had lower indices of absolute soil penetration resistance than the recultivated soil. The maximum average value of soil penetration resistance of the chernozem was $2.67 \pm 0.07 \mathrm{MPa}$, while for technical soil it was $8.42 \pm 0.33 \mathrm{MPa}$.

The values of black and technical soil penetration resistance were more variable in the upper layers of the soil. The greatest values of the coefficient of variation correspond to the layer of $5-10 \mathrm{~cm}$ from the surface in all cases (33.09-42.7\%). 
A higher level of spatial dependence is described in the data for the upper layers of the soils studied.

The radius of influence in the chernozem decreased with depth, while it increased in the reclaimed soil. Absolute values of the radius of influence in the chernozem were higher than those of technical soil.

A high level of dependence of soil penetration resistance data distribution was revealed over the two years researched. The discovered relations in the technical soil were weaker than those of the chernozem. Reliable correlations between the data of the different years in the technical soil were mostly negative.

\section{References}

Alvarez, C.R., Taboada, M.A., Gutierrez Boem, F.H., Bono, A., Fernández, P. L. \& Prystupa P. (2009). Topsoil properties as affected by tillage systems in the Rolling Pampa Region of Argentina. Soil Sci. Soc. Am. J., 73, 1242-1250. DOI: $10.2136 /$ sssaj2008.0246.

Anand, M., Tucker, B.C. \& Desrochers R. (2002). Ecological monitoring of terrestrial ecosystem recovery from manmade perturbation: assessing community complexity. In Proceedings of the 10th International Conference on Modelling, Monitoring and Management of Air Pollution (pp. 341-350). July 1-3, 2002, Segovia, Spain. Southampton: WITPress.

Andrusevich, E.V. \& Shtirts Yu.A. (2014). Ecologiocal diversity of vegetation on lithogenic soil in the reclamation land of the Nicopol manganese ore basin. Industrial Botany, 14, 115-127.

Bajla, B.C. \& Minarik J. (2003). Navrh metody na meranie okamzitej vlhkosti pody u hrot epenetrometra. Acta Technologica Agriculturae, 4, 93-96.

Bengough, A.G., Campbell, D.J. \& O’Sullivan M.F. (2001). Penetrometer techniques in relation to soil compaction and root growth. In K.A. Smith \& C.E. Mullins (Eds.), Soil and environmental analysis. Physical methods (pp. 377-403). New York: Marcel Dekker.

Bölenius, E., Rogstrand, G., Arvidsson, J., Thylén, L. \& Stenberg B. (2006). On-the-go measurements of soil penetration resistance on a Swedish Eutric Cambisol. In Proceedings of International Soil Tillage Research Organization $17^{\text {th }}$ Triennal Conference (pp. 867-870). Kiel.

Brady, N.C. \& Weil R.R. (2002). The nature and properties of soils. Upper Saddle River: Prentice Hall.

Calderon, V.C.A., Martinez, M.L.J. \& Giraldo Henao R. (2008). Spatial variability of soil properties and yield relationship in a mango crop (Mangifera indica L.). Revista Brasileira de Fruticultura 30(4), 1146-1151. DOI: 10.1590/S0100-29452008000400049.

Cecilia, M., Jesus, H.C. \& Cortes C.A. (2012). Soil penetration resistance analysis by multivariate and geostatistical methods. Engenharia Agricola, 32(1), 91-101. DOI: 10.1590/S0100-69162012000100010.

Chesson, P. (2000). Mechanisms of maintenance of species diversity. Annu. Rev. Ecol. Syst., 31, 343-366.

Chien, Y.J., Lee, D.Y., Guo, H.Y. \& Houng K.H. (1997). Geostatistical analysis of soil properties of mid - west Taiwan soils. Soil Sci., 162, 291-298.

Demidov, A.A., Kobets, A.S., Gritsan, Y.I. \& Zukov A.V. (2013). Spatial agroecology and land reclamation: monograph. Dnepropetrovsk: Publishing house 'Svidler AL'

Diggle, P.J. \& Ribeiro J.P. Jr. (2007). Model based geostatistics. Sao Paulo: Springer.

Ditsch, D.C. \& Collins M. (2000). Reclamation consideration for pasture and hay lands receiving sixty-six centimeters or more precipitation annually. Reclamation of drastically disturbed lands. Agronomy Monograph (pp. 24-273). Madison: ASA, CSSA, SSSA.

Gerasimova, M.I., Stroganova, M.N., Mozharova, M.V. \& Prokofieva T.V. (2003). Anthropogenic soils (genesis, geography, recultivation) (in Russian). Smolensk: Oykumena.

Godefroid, S. \& Koedam N. (2003). How important are large vs. small forest remnants for the conservation of the woodland flora in an urban context? Glob. Ecol. Biogeogr., 12, 287-298. DOI: 10.1046/j.1466-822X.2003.00035.x.

Grunwald, S., Mc Sweeney, K., Rooney, D.J. \& Lowery B. (2001). Soil layer models created with profile cone penetrometer data. Geoderma, 103(1-2), 181-201. DOI: 10.1016/S0016-7061(01)00076-3.

Karpachevskij, L.O., Zubkova, T.A., Tashninova, L.N. \& Rudenko R.N. (2007). Soil cover and forest biogeoceonosis- 
parcelar structure (in Russian). Russian Forest Sciences, 6, 107-113.

Langmaack, M., Schrader, S., Rapp-Bernhardt, U. \& Kotzke K. (2002). Soil structure rehabilitation of arable soil degraded by compaction. Geoderma, 105, 141-152. DOI: 10.1016/S0016-7061(01)00097-0.

Legendre, P. \& Fortin M.J. (1989). Spatial pattern and ecological analysis. Vegetatio, 80, 107-138. DOI: 10.1007/ BF00048036.

Lipiec, J. \& Tarkiewicz S. (1990, 1991). The influence of water content and bulk density on penetration resistance of two soils. Zeszyty Problemowe Postępów Nauk Rolniczych, 338, 99-105.

Medvedev, V.V. (2009). Soil penetration resistance and penetrographs in studies of tillage technologies (in Russian). Eurasian Soil Science, 42(3), 299-309. DOI: 10.1134/S1064229309030077.

Medvedev, V.V. (2014). The contents and laws of soil anthropogenous evolution (in Russian). Gruntoznavstvo (Soil Science), 15(1-2), 17-30. DOI: 10.15421/041402.

Montagu, K.D., Conroy, J.P. \& Atwell B.J. (2001). The position of localized soil compaction determines root and subsequent shoot growth responses. J. Exp. Bot., 52, 2127-2133. DOI: 10.1093/jexbot/52.364.2127.

Nikiforova, E.M. \& Solntseva N.P (1982). Geochemistry of technogenic flow and aureoles of pollution in coal mining areas (using the Kizelovsky basin as an example) (in Russian). In Geochemistry of landscapes and geography of soils (pp. 100-128). Moscow: MSU.

Serafim, M.E., Vitorino, A.C.T., Peixoto, P.P.P., Souza, C.M.A. \& Carvalho D.F. (2008). Intervalo hidrico otimo em um latossolo vermelho distroferrico sob diferentes sistemas de producao. Engenharia Agricola, 28(4), 654-665. DOI: $10.1590 /$ S0100-69162008000400005.

Solntseva, N.P. \& Rubilina N.E. (1987). Morphology of soils transformed in coal mining. Eurasian Soil Science, 2, 104-108.

Targulian, V.O. \& Goryachkin S.V. (Eds.) (2008). Soil memory: Soil as a memory of biosphere-geosphere-anthroposphere interactions. Moscov: LKI Publishers.

Topp, G.C., Lapen, D.R., Edwards, M.J. \& Young G.D. (2003). Laboratory calibration, in-field validation and use of a soil penetrometer measuring cone resistance and water content. Vadose Zone Journal, 2, 633-641. DOI: 10.2136/vzj2003.6330.

Uzbek, I.Kh., Volokh, P.V, Dyrda, V.I. \& Demidov A.A. (2010). Reclamation of disturbed lands as a sustainable development of complex techno-ecosystems: monograph (in Russian). Dnipropetrovsk: Porogi.

Umarova, A.B., Shein, E.V., Milanovskiy, E.Yu. \& Dembovetskiy A.V. (2013). Specific water regime in technogenic soils: Preferential water flow formation. Procedia Environmental Sciences, 19, 558-563. DOI:10.1016/j. proenv.2013.06.063

Vachel, J. \& Ehrlich P. (1988). Vyuzifi penetrometricki metody mereni pevnosti zemin v prbzkumech pro odvodneni. Vedpr. Vu zurod. Zemedel., 5, 131-140.

Vanags, C., Minasny, B. \& McBratney A.B. (2004). The dynamic penetrometer for assessment of soil mechanical resistance. In Supersoil 2004: Proceeding of the 3th Australian New Zealand Conference. University of Sydney, Australia. URL: http://www.regional.org.au/au/asssi/supersoil2004/s14/poster/1565_vanagsc.htm.

Verones J.V., Carvalho, M.P., Dafonte, J., Freddi, O.S., Vidal Vazquez, E. \& Ingaramo O.E. (2006). Spatial variability of soil water content and mechanical resistance of Brazilian ferralsol. Soil Tillage Res., 85(1-2), 166-177. DOI:10.1016/j.still.2005.01.018

Webster, R. \& Oliver M.A. (2007). Geostatistics for environmental scientist. Cornwall: John Wiley \& Sons.

Yeterevska, L.V., Momot, G.F. \& Lehtsier L.V. (2008). Recultivated soils establishment, diagnostic, eststimation. Gruntoznavstvo (Soil Science), 9(3-4), 147-150.

Young, G.D., Adams, B.A. \& Topp G.C. (2000). A portable data collection system for simultaneous cone penetrometer force and volumetric soil water content measurements. Can. J. Soil Sci., 80, 23-31. DOI:10.4141/S99-025.

Zhukov, A.V., Zadorozhnaya, G.A. \& Lyadskaya I.V. (2013). Aggregate structure of industrial soils of the Nikopol manganese ore basin. Biological Bulletin of Bogdan Chmelnitskiy Melitopol State Pedagogical University, 3(3), 274-286.

Zhukov, A.V. \& Zadorozhnaya G.A. (2015). Ecomorphic organisation of the soil body: geostatistical approach (in Ukrainian). Studia Biologica, 9(3-4), 119-128.

Zhukov, A. \& Zadorozhnaya G. (2016). Spatial heterogeneity of mechanical impedance of atypical chernozem: the ecological approach. Ekológia (Bratislava), 35(3), 263-278. DOI: 10.1515/eko-2016-0021. 